University for Business and Technology in Kosovo

UBT Knowledge Center

UBT International Conference

2014 UBT International Conference

Nov 7th, 4:30 PM - 4:45 PM

\title{
The spatial nature of entrepreneurship, economic prosperity and, the informal economy
}

\author{
Besnik Skenderi \\ University for Business and Technology, besnik_skenderi@yahoo.com \\ Diamanta Skenderi \\ University for Business and Technology, diamanta_skenderi@yahoo.com
}

Follow this and additional works at: https://knowledgecenter.ubt-uni.net/conference

Part of the Business Commons

\section{Recommended Citation}

Skenderi, Besnik and Skenderi, Diamanta, "The spatial nature of entrepreneurship, economic prosperity and, the informal economy" (2014). UBT International Conference. 50.

https://knowledgecenter.ubt-uni.net/conference/2014/all-events/50

This Event is brought to you for free and open access by the Publication and Journals at UBT Knowledge Center. It has been accepted for inclusion in UBT International Conference by an authorized administrator of UBT Knowledge Center. For more information, please contact knowledge.center@ubt-uni.net. 


\title{
The spatial nature of entrepreneurship, economic prosperity and, the informal economy
}

\author{
Besnik Skenderi ${ }^{1}$, Diamanta Skenderi ${ }^{2}$ \\ ${ }^{1,2}$ University for Business and Technology \\ Tax Administration of Kosovo \\ besnik_skenderi@yahoo.com ${ }^{1}$,diamanta_skenderi@yahoo.com ${ }^{2}$
}

\begin{abstract}
Businesses are not refining products and they are not adding any value on the sold products, but they are using the opportunity to purchase goods with lower price and then sell those products with a higher price, where the difference between those prices is profit. In addition, knowledge is an important factor, which explains the arrays of known profit opportunities, which entrepreneurs face, and those opportunities are not equally discoverable in all locations. The issue with classical and neoclassical models of land rent is a fact that they were based on an assumption where perfect knowledge of transportation requirements and transportation costs exist. Since all companies need to have space to produce and to operate, they own or rent land or real estate. Because of the rent, businesses are changing prices in the land market.
\end{abstract}

Keywords: Land, Knowledge, Kirzner's theory, Entrepreneurship, The market of land

\section{Kirzners's Theory of Entrepreneurship}

Coordination of markets and knowledge has been explained with Kirzner's theory, which falls on the category of non-spatial theories. This theory defines entrepreneurship action as "an attempt to profit from perceived discrepancies between buying and selling prices" (Andersson, 2005, p. 22). According to this theory, businesses are not refining products and they are not adding any value on the sold products, but they are using the opportunity to purchase goods with lower price and then sell those products with a higher price, where the difference between those prices is profit. According Kirzner's theory, entrepreneurs are competing with each other in different markets and this competition leads to more correct prices. Identified mistakes based on Kirzner's theory are mistakes related to human nature, like missing opportunity to identify profit and the exploration of a non-existing profit opportunity. While the first mistake is not triggering any action in as at the same time it is not crating any cost, the second one is creating costs and since there will not be any profit, created cost will be treated as a loss.

Kirzner's theory can be evaluated in trade relationships between businesses and consumers, only if customer's knowledge and access to the information is ignored, otherwise in the actual business environment customers are representing decision-making force, since they have access to information regarding the prices of goods, which they are intending to purchase.

\section{Knowledge and Location}

Knowledge is an important factor which explains the arrays of known profit opportunities which entrepreneurs face (Andersson, 2005), and those opportunities are not equally discoverable in all locations. Knowledge consists from knowing facts and theories (knowing that) and from ability to undertake right actions in order to achieve desirable results (knowing how). In actual business environment "knowing that" knowledge is less costly and it is accessible for businesses and that because of the use of technology and just in time information. Regarding the "know how" knowledge (Andersson, 2005) states:"each location is associated with a unique agglomeration of knowledge, which 
determines the array of profit opportunities that entrepreneurs may discover", (p.23). Knowledge is not considered as an asset but it is considered as a cost until there is a need to use it and: "the entrepreneur is the key agent who realizes knowledge spillovers from the source to final users". (Russo, Reggiani, \& Nijkamp, 2007, p.791). Comparing Kirzner's theoretic approach, with practice correlation can be established with a case of Post and Telecom of Kosovo (PTK), for example in Training and Development Centre (TDC) which is operating within PTK, three persons are in a process of finishing doctoral studies and they are working part time as professors at university. Those persons in PTK are coordinating training activities and company rarely is using their knowledge to gain the profit.

Location plays an important role in transferring knowledge, since interaction between interested parties will transmit tactic knowledge and will update capacity.

Since Kirzner's theory of entrepreneurship it is not containing explicit treatment of time and place it makes this theory incomplete (Andersson, 2005). Comparing this theory with actual business environment where distribution channels are in place and were outsourcing is implemented by many companies, the importance of "know how" knowledge and importance of location are dimming.

Based on classical and neoclassical theories of land rent, "price of the land is a function of the cost of transporting various products to buyers" (Andersson, 2005, p.25) and that familiarity of transportation costs would lead to a spatial separation of land uses. The issue with classical and neoclassical models of land rent is a fact that they were based on an assumption where perfect knowledge of transportation requirements and transportation costs exist. In practice, transportation requirements and costs can change, because of environment protection laws, (In my country, Republic of Kosovo, it was forbidden to transport diesel and petrol in roads near lakes). In addition, political situation could influence on changing the transport costs, for example roadblocks and criminal activities (In Republic of Kosovo, since August 2011, 20(\%) of the roads are blocked with barricades and as a result of this transport is conducted in alternative roads).

Entrepreneurships are selecting location based on their knowledge regarding profit opportunities, and based on the historical information about profit, prices and infrastructural characteristics of location. Entrepreneurships should carefully select locations because they may benefit also from 'tactic knowledge' that may be associated with a specific location.

\section{The Market for Land}

Since all companies need to have space to produce and to operate, they own or rent land or real estate. Because of the rent, businesses are changing prices in the land market. (Andersson, 2005). Market of land is influenced from population growths, and in many countries farmland is used for building residences. Those residences are sold and rented and this has impact on increasing price of the land. Despite this because of permanent increased need for fuel and because of innovation of bio fuel, the price of the land has increased. Landowners are aware of the increased value of their land and in correlation with increased value they will increase the rent. In Republic of Kosovo, after the war in 1999, all farm lands around the capital city are sold to building companies which had built apartments and office space. Because of this action price of farm land had increased from 3,000€ for $10 \mathrm{~m} 2$ to $11,000 €$ for $10 \mathrm{~m} 2$.

\section{Profits, Rents, and Migration}

Labor is one the main factors of production, many countries are facing with structural unemployment, since they do not have skilled labor force for particular jobs. Some countries are facing with 'old age population' phenomenon, (western European countries), while in some countries because of their culture companies cannot find labor for some specific jobs, for example in my country it is very difficult to hire a baby sitter. 
However, entrepreneurial activities are creating benefits for community sine they are improving local economy and creating sustainability, (Sumner, 2009). Local economy improvement and sustainability is achieved through process of recruiting labor.

Labor is influencing factor on the profit of companies and according (Andersson, 2005) labor is "the entrepreneurial process that coordinates the two spatially distinct markets."(p.29). Migration is playing important role on the profit realization for companies since companies are hiring cheaper labor and sometimes even more skilled labor which is available on the original location where the businesses are operating. For example, Germany is recruiting lot of IT experts from India. Another example of economic migration is example of Greece, where 400,000 people from Albania are working in Greece, mainly in the agriculture. In one way, migrants are creating profits for companies, but in a same time, migrants will need accommodation. Because of the increased need for apartments, rent will increase and in a same time value of the land will be higher and from those changes also the businesses would be forced to pay higher rent for lend which they are renting. Process is migration is creating welfare for business and for migrants, but there are also cases where migrants are underpaid and they are working in very difficult conditions, where health and safety procedures are not followed.

Entrepreneurs are coordinating the labor market, and without this coordination migration would be much higher.

\section{Conclusions}

The spatial nature of entrepreneurship is explained with Kirzner's theory of entrepreneurship and with Fetters theory of rent. Fetters theory is explaining how rent has impact on increasing prices and this theory can be applied also in the actual business and technological environment.

Kirzner's theory, explains coordination of markets and knowledge, and entrepreneurs are using the opportunity to purchase goods with lower price and then sell those products with a higher price, where the difference between those prices is profit. Because of competition between entrepreneurs, prices that are more accurate are appearing in the market. An entrepreneur seems to make two common mistakes, missing opportunity to identify profit and the exploration of a non-existing profit opportunity. This theory ignores knowledge and access to the information by customers, since in the actual business environment customers are representing decision-making force.

Knowledge and location plays important role for profit opportunities, knowledge that consists from 'know that' and 'know how', and is helping to identify profit opportunities, sometimes this opportunity is not discoverable in all locations. In actual business environment knowledge seems to be available to anybody who is interested and that because use of technology is making possible access to just in time information. Knowledge which possess staff is not considered as an asset, but in real business environment it can be used as competitive advantage. Location plays important role in transferring knowledge, since interaction between interested parties will transmit tactic knowledge and will update capacity, but as a result of new communication technologies like internet, role of the location regarding knowledge is dimming. This approach cannot be implemented for businesses that are offending online services or for companies which are outsourcing some of their activities.

"Price of the land in a function of the cost of transporting various products to buyers" (Andersson, 2005, p.25), with assumption that perfect knowledge of transport needs and costs exists, but it is different picture in reality. Because of competition, government rules and major force (natural disaster, war, terrorist activity) situation in a location regarding the transport can change at any moment.

Entrepreneurships should carefully select locations because they may benefit also from 'tactic knowledge' that may be associated with a specific location.

Market of land is not stabile market, because companies are renting or purchasing lend or real estates in order to place their machinery which is used for production of goods. Since there is a need for land, landowners are increasing price of the rent and this is influencing the prices of goods that are sold by companies. Because of economic development and population growth there is a need for new apartments that are built in a farmlands, again price of the land is increasing. Also the production of bio fuel will have impact on increasing price of the land in a near future. 
Labor is one the main factors of production and many companies have difficulties to hire cheap and skilled labor force. In order to solve this problem some companies are outsourcing some of their activities in other countries. Companies are outsourcing their activities because they can find cheaper labor force in third world countries, or because tax benefits which are available in other countries. Process of migration it is creating welfare for companies and it creates welfare for employees, but since the migrant works, need place to stay and live the prices of the rent for real estates are increasing in the location where companies are operating. Since the prices of rent are increasing, also the value of the land will increase and companies will be forced to pay higher rent for premises and lend which are renting. Therefore, in the end of the day because of migration, prices of labor, transport and products will be higher. Another negative impact of migration is fact that some migrants are underpaid and they have difficult working conditions.

\section{References}

1 Andersson, D. E. (2005). The spatial nature of entrepreneurship. The Quarterly Journal of Austrian Economics, 8(2), 21-34.

2 Russo, G., Reggiani, A., \& Nijkamp, P. (2007). Spatial activity and labour market patterns a connectivity analysis of commuting flows in Germany. Annals of Regional Science, 41(4), 789-811.

3 Sumner, G. (2009). Spatial layout, entrepreneurship and economic prosperity. Local Economy, 24(6-7), 502-522. 